\title{
Effects of financial openness on renewable energy investments expansion in Latin American countries
}

\author{
Matheus Koengkan ${ }^{*}, 1$, José Alberto Fuinhas ${ }^{2}$, and Isabel Vieira ${ }^{1}$ \\ ${ }^{1}$ CEFAGE-UE and Department of Economics, University of Évora, Portugal \\ ${ }^{2}$ NECE-UBI, CeBER, and Faculty of Economics, University of Coimbra, Portugal
}

\begin{abstract}
This investigation approaches the effects of financial openness on renewable energy investments. With the purpose of the realisation this study, the installed capacity of renewable energy was used as proxy o renewable energy investments, and ten Latin American countries from 1980 to 2014 were utilised. This investigation used as methodology two models, such as the PARDL in the form of UECM as a general model, and PVAR model and Panel Granger causality Wald test as a robustness check. The empirical results indicated that the per capita economic growth in the short-run has a positive impact on the installed capacity of renewable energy, while the variable financial openness and general government capital stock per capita in the long-run exerts a positive effect. The PVAR model pointed out to a positive impact of per capita economic growth, financial openness, and general government capital stock per capita in the short-run. The Panel Granger causality Wald test revealed the existence of a bi-directional causality between The results of the panel Granger causality Wald test point to the existence of bi-directional causality between: (i) installed capacity of renewable energy and per capita economic growth; (ii) financial openness and installed capacity; (iii) financial openness and per capita economic growth; (iv) installed capacity of renewable energy and general government capital stock per capita; and (v) general government capital stock per capita and per capita economic growth.
\end{abstract}

Keywords: Energy economics; Econometrics; Financial openness; Investments; Renewable energy; Latin America.

\footnotetext{
* Corresponding Author: matheuskoen@hotmail.com.br; Department of Economics, University of Évora, Colégio do Espírito Santo, Largo dos Colegiais, 2 ,7000-803 Évora, Portugal.

${ }^{1,3}$ Research supported by:National Funds of the FCT - Portuguese Foundation for Science and Technology within the project UID/ECO/04007/2019.

${ }^{2}$ Faculty of Economics, University of Coimbra, Av. Dr. Dias da Silva 165, 3004-512 Coimbra, Portugal. Centre for Business and Economics Research - CeBER.

${ }^{2}$ Research supported by: NECE, R\&D unit funded by the FCT - Portuguese Foundation for the Development of Science and Technology, Ministry of Science, Technology and Higher Education, project UID/GES/04630/2019.
} 


\section{Introduction}

This paper assesses the impact of financial openness on the dissemination of renewable energy investments in Latin America. Non-renewable resources, such as coal and oil, have for long been used as sources of energy and were considered key for economic long term growth. However, the intensive use of such resources has negative environmental consequences, inter alia fuelling climate change. In order to achieve sustainable development without compromising the environment, it is crucial to count with reliable, affordable and economically viable renewable energy services [47]. To this end, financial funds are required and thus financial liberalisation may play a significant role.

The development of renewable energy sources enhances the diversification of the energy matrix and mitigates the consumption of non-renewable energy resources and $\mathrm{CO}_{2}$ emissions while increasing energy security [33]. The improvement of renewable energy technologies is considered an ideal solution for achieving sustainable development without degrading the environment. Many countries have been promoting the development of renewable energies. In Latin America, the process began in the mid-1970s, in Brazil with hydropower plants in 1973, and biofuels in 1975; in Uruguay and Paraguay with hydropower plants also in 1973, followed by Argentina with biomass, biogas, hydropower plants, geothermal, wind, waves, and photovoltaic plants in 1998, and Venezuela with hydropower plants in 2001 [18]. In Latin America, the consumption of energy from renewable sources represented 35\% of the total energy consumption in 2013 [22], and investments in renewable energy sources grew 13\% between 2000 and 2013 [20].

The increase of investment in, and consumption of, renewable energy is related to the rapid process of economic growth, financial liberalisation, and capital stock accumulation resulting from several economic reforms and political transitions in the last forty years which, to some extent, are still ongoing in the region [20]. Latin American countries' per capita Gross Domestic Product (GDP) has registered average annual growth rates of approximately $3.0 \%$. The value of per capita GDP (in the current United States - US - dollars) was 664.179 US\$ in 1971 and 10,278.241 US\$ in 2014 [46]. The consumption of energy has followed a similar path, evolving from a value of 248 million tonnes of oil equivalent (MTOE) in 1971 to 848 MTOE in 2013. Between 1971 and 2013 the consumption of energy grew by approximately 5.4\% [6].

Financial liberalisation in Latin America has undergone distinct stages. In the 1960s, a period of import-substitution industrialisation, state control over the financial sector prevailed, leading to significant fiscal costs related to the mismanagement of public banks and atrophied financial systems [26]. The 1980s, a period of economic stagnation and accelerated inflation designated as "the lost decade", comprised the 1982 to 1989 debt crisis [5], and witnessed changes in the management of economic policies. The Brady plan, designed in the US to address Latin America's debt crisis, restored the inflow of foreign capital to the region in the early 1990s. A set of comprehensive economic reforms ensued. For example, Argentina, Brazil, and Mexico introduced economic stabilisation programmes and initiated a process of trade and financial liberalisation with the privatisation of some state-owned companies [5]. The adoption of such reforms boosted capital mobility in Latin America (from about $40 \%$ in the 1980s to $75 \%$ in the 1990s [5]).

These developments have motivated the central question of this investigation: What is the effect of financial openness on renewable energy investments diffusion in Latin America? The more specific issues resulting from this main interrogation are: (a) What are the possible 
explanations for the identified effects? (b) What is the causality nexus underlying the links between the assessed variables in Latin American countries? To answer such questions, the impact of financial openness on the installed capacity of renewable energy will be examined using a dataset comprising ten Latin American countries in the period from 1980 to 2014, and using Panel Autoregressive Distributed Lags (PARDL) in the form of an unrestricted error-correction model (UECM). A panel vector autoregression (PVAR) model and panel Granger causality Wald tests are used as robustness tests.

This investigation is innovative and adds to the literature in various ways: (a) it is the first assessment of the impact of financial openness on the installed capacity of renewable energy aiming at explaining the investments diffusion of this kind of source; (b) it considers financial openness and general government capital stock as independent variables in order to explain the increase of installed capacity; (c) it uses PARDL in the form of a UECM as a general model, and a PVAR model and a Panel Granger causality Wald test as robustness checks; and (d) it focus on Latin America and investigates a group of countries not previously considered in similar research efforts. Previous assessments have solely studied countries in Asia, the Middle East, and Europe. Yet, Latin America is of interest not only because it was not studied before, but also for its social, political, and economic specificities that may help to explain the relationships between the variables of interest in this investigation. Other than its academic interest, our empirical analysis is also of use for Latin American policymakers as it may help in the design of effective policies aimed at promoting the development of renewable energy technologies.

After these introductory remarks, the study is organised as follows: section 2 reviews the relevant literature; section 3 presents the data and the adopted methodology; the results of the empirical analysis and the robustness checks are presented in sections 4 and 5, respectively, and discussed in section 6; section 7 concludes and debates policy implications.

\section{Literature review}

The impact of financial openness on the diffusion of renewable energy investments has not received much attention from researches and the scarcity of academic studies impairs understanding of how the two interact. In the few existing assessments, the choices for the dependent variables have been the consumption and/or the production of renewable energy, renewable energy technologies, and the installed capacity of renewable energy, whereas financial development, financial flows and foreign direct investment (FDI) are examples of independent variables (e.g., Sbia et al., [36]; Rodríguez et al., [35]; Kim and Park, [25]; Mazzucato and Semieniuk [30]; Roubaud and Shahbaz [34]). Distinct proxies have been chosen for investments in renewable energies, and no consensus has been reached concerning the best choice in this regard. In what concerns financial openness, the proposal of a financial openness index by Chinn and Ito [8] has increased the number of proxy possibilities.

The absence of studies considering financial openness as a possible determinant of the diffusion of renewable energy investments leads to the consideration of proximate analyses when attempting to survey the relevant literature. This is the case, for instance, of Kim and Park, [25] who investigated the effects of financial development on the expansion of the renewable energy sector. The authors used ordinary least squares (OLS) and considered a sample of data comprising thirty countries and the period from 2000 to 2013. They concluded that financial development promotes renewable energy investments by reducing financing costs and overcoming adverse selection and moral hazard problems, an impact that is especially relevant for energies more intensive in capital, and therefore more dependent on external funds. Mazzucato and Semieniuk [30] studied the influence of public and private financing of renewable energy projects in China, Spain, the US, and Kenya, from 2004 to 2014. Although both sources appeared to be relevant, 
the authors suggested that a finer distinction of funding suppliers would be needed to understand their importance fully. The study also pointed out that financing by public investors had played an increasingly significant role in the development of renewable energy technologies in the assessed countries and that it was the sole reason for the growth of asset financing in that context. In comparison with private investors, public actors tended to choose higher risk technologies. Rodríguez et al., [35] added that public investment supported renewable energy projects that failed to attract private financing and that public policies appeared to have had a small impact in mobilising the financing capacity of the private sector.

Sbia et al. [36] investigated the impact of FDI, renewable energy, trade openness, $\mathrm{CO}_{2}$ emissions and economic growth on energy demand in the United Arab Emirates. The study covered the period between 1975 and 2011 and the adopted methodologies were ARDL bounds testing and vector error correction model (VECM) Granger causality. Results suggested that FDI had a positive impact on renewable energy consumption via financial development. The latter boosted public and private capital stocks, decreased financing costs, stimulated economic activity and, subsequently, the consumption of renewable energy. Such results confirm those of Kim and Park, [25]. Other authors, as Koengkan et al., [21]; Shahbaz et al., [37], and Islam et al., [17], concur in defending that reduced financing costs resulting from financial openness increase households' purchasing power and firms' investments, both of which stimulate economic activity and, subsequently, the consumption of energy. In order to meet such increased demand, new investments in renewable energy sources are required. Financial openness, therefore, exerts an indirect positive impact in the development of renewable energies.

This review of studies on proximate topics indicates that various questions are still unanswered. The first and most significant gap in the literature is the absence of studies addressing the impact of financial openness on renewable energy investments diffusion. Indeed, apart from the cited analyses, there are studies focusing solely on the effects of financial development on the consumption of energy. The possible relationship between financial openness and the installed capacity of renewable energy is thus still unexplored. The second identified gap is the nonconsideration of the stock of public capital as a determinant of the diffusion of renewable energy. Another gap, which naturally runs from the thin number of empirical analyses, is the limited methodological spectrum of existing research. For instance, the ARDL approach in the form of the UECM model was not previously considered. There is also a lack of robustness procedures, such as the use of a PVAR model and Panel Granger causality Wald test, which are especially adequate in this context. Finally, researchers have mainly focused on Asia, Europe and the Middle East, disregarding Latin American and Caribbean countries. There are hence various reasons justifying the interest of the empirical assessment developed in the next sections.

\section{Methodology and Data}

Section 3 is divided into two parts: the first describes the adopted methodological strategy and the second presents the data and the variables used in the search for answers to our research questions.

\subsection{Methodology}

The PARDL model in the form of a UECM is used with the purpose of decomposing the total effects of the variables into their short- and long-run components [20]. This model was developed by Granger [12] and by Engle and Granger [10] and was upgraded by Johansen and Juselius [19] who introduced cointegration techniques that allow the identification of long-run relationships among non-stationary series and their parametrisation into an Error Correction Model (ECM) [31]. 
The PARDL model was preferred in this study for its many advantages, namely: (a) it is suitable to deal with cointegration; (b) it allows the analysis of $\mathrm{I}(0)$ and $\mathrm{I}(1)$ variables; (c) it can produce efficient parameter estimates with relatively small samples; (d) it is robust in the presence of endogeneity. The model is also more flexible than alternatives such as the Generalized Method of Moments (GMM), Dynamic OLS (DOLS), and Fully Modified OLS (FMOLS) [20].

The general PARDL model follows the specification of Eq. (1):

$$
\begin{aligned}
& \text { DLnIREC } i t=\alpha_{i}+\beta_{1 i 1} D_{\text {LnGDP }}+\gamma_{1 i 1} \text { LnIREC }_{i t-1}+\gamma_{1 i 2} \text { LnFOPI }_{i t-1}+ \\
& \gamma_{1 i 3} \text { LnKPUBLIC }_{i t-1}+\varepsilon_{1 i t} .
\end{aligned}
$$

where the $\alpha_{i}$ represents the intercept, $\beta_{i k}$ and $\gamma_{i k}$, with $\mathrm{k}=1, \ldots, 3$, denote the estimated parameters, and $\varepsilon_{i t}$ is the error term. The prefixes "Ln" and "DLn" denote natural logarithms and first-differences, respectively.

Before the estimation of the PARDL model, it is necessary to examine the characteristics of the cross sections and time series, as well as to check for the existence of specificities which, if not taken into account, may produce inconsistent and incorrect results. To this end, the best econometric practices recommend performing a set of preliminary and specification tests before estimating the model of interest. The following tests are thus executed:

(i) Preliminary tests: (a)Variance Inflation Factor (VIF) to check for the existence of multicollinearity; (b) Cross-section Dependence (CSD) test [41]; (c) 2nd generation unit root test (CIPS-test) [42] for the presence of unit roots; (d) 2nd generation cointegration test (e.g., Westerlund [44]; Aydin [3]) to assess if the series are cointegrated; (e); Mean Group (MG), Fixed Effects (FE), and Pooled Mean Group (PMG) estimators, and (f) Hausman test to identify heterogeneity, i.e. whether the panel has random effects (RE) or fixed effects (FE).

(ii) Specification tests: (a) Modified Wald test (Greene, [13]) to check for the presence of group-wise heteroscedasticity; (b) Wooldridge test (Wooldridge, [45]) to confirm the existence of serial correlation; and (c) Breusch and Pagan Lagrangian Multiplier test (Breusch and Pagan [7]) for cross-sectional correlation in the fixed effects model. The latter is used due to the large $\mathrm{T}$ (number of time-series observations) and the small $\mathrm{N}$ (number of cross-sectional observations) in the panel.

To appraise the robustness of the model, Panel Vector Autoregression (PVAR) is run to assess Granger causality amongst variables (via Wald test). This model was proposed by HoltzEakin et al., [14] as a substitute for multivariate simultaneous equation models. According to Antonakakis et al., [2] PVAR presents various advantages: (i) it permits addressing endogeneity problems; (ii) it allows including country fixed-effects that capture the time-invariant components; (iii) it is useful when there is poor information concerning the relationships amongst variables; (iv) it can determine whether the impact of the variables is felt in the short-run, in the long-run or both, and v) it takes into account global shocks that simultaneously impact all the countries in the sample. PVAR thus complements PARDL. The general PVAR model is represented by the following linear equation:

$$
\chi_{i t}=\Gamma_{0}+\Gamma_{1} \chi_{i t-1}+\Gamma_{2} \chi_{i t-2}+\mu_{i}+e_{c, t}+\varepsilon_{t}
$$

where, $\chi_{i t}$ is the vector of dependent variables in first-differences and natural logarithms (e.g., LnIREC, DLnGDP, LnFOPI, and DLnKPUBLIC). The use of variables in first-differences and natural logarithms follows from PVAR's prerequisite that all variables must be I(0) (See Table 3 below); $\Gamma_{1}, \Gamma_{2}$ are the parameters to be estimated, and $\varepsilon_{t}$ is the vector of dependent variables in a panel of fixed effects and idiosyncratic errors. After running the PVAR regression, the Panel Granger causality Wald test developed by Abrigo and Love [1] is performed. Estimation and testing procedures are conducted using Stata 15.0. 


\subsection{Data}

With the intention of investigating the impact of financial openness on the installed capacity of renewable energy, a panel of ten Latin American countries (Argentina, Bolivia, Brazil, Chile, Colombia, Ecuador, Mexico, Nicaragua, Peru, and Uruguay) is considered and data collected for the period from 1980 to 2014 . The time span is determined by data availability (the ARDL model requires balanced panels). The choice of this group of countries is justified, not only by the lack of previous research on Latin America, but also because they have experienced, during the analysed time frame, processes of rapid growth in both economic terms and in what concerns the installed capacity of renewable energy, and have also been experiencing increasing financial integration.

The raw data utilised in the empirical analysis is as follows:

(a) Dependent variable - the Installed Capacity of Renewable Energy (from biomass, hydropower, solar, photovoltaic, wind, wave, and waste) in Million Kilowatts (IREC) is a proxy for renewable energy investments - data retrieved from the International Energy Administration (IEA) [48];

(b) Independent variables - (i) Gross Domestic Production (GDP) in constant local currency units (LCU), retrieved from World Bank Open Data [46]; (ii) Financial openness index (FOPI) (whose impact on installed capacity of renewable energy is of uttermost interest in this study) is available in the Chinn-Ito Index [8]. This index is based on the binary dummy variables that codify the tabulation of restrictions on cross-border financial transactions reported in the International Monetary Fund (IMF) Annual Report on Exchange Arrangements and Exchange Restrictions. Given that the financial openness index contains some zeros, we work with a transformed set of values obtained by adding 1 to the original financial openness index; and (iii) General government capital stock (KPUBLIC) in billions of constant 2011 US dollars, available from the "Investment and Capital Stock Dataset" released by the IMF [16]. Table 1 displays the variables' description and summary statistics.

Table 1. Variables' description and summary statistics

\begin{tabular}{|c|c|c|c|c|c|c|}
\hline \multirow{2}{*}{ Variables } & \multirow{2}{*}{ Description } & \multicolumn{5}{|c|}{ Descriptive Statistics } \\
\hline & & Obs. & Mean & Std. Dev. & Min & Max \\
\hline LnIREC & $\begin{array}{l}\text { Natural logarithms of per capita } \\
\text { Installed Capacity of Renewable } \\
\text { Energy (Million kilowatts). } \\
\text { Natural logarithms of per capita }\end{array}$ & 350 & 2.4854 & 1.6384 & -1.0526 & 6.1291 \\
\hline LnGDP & $\begin{array}{l}\text { Gross Domestic Production (GDP), } \\
\text { in constant LCU. }\end{array}$ & 350 & 10.7417 & 2.6517 & 7.6628 & 16.1937 \\
\hline LnFOPI & $\begin{array}{l}\text { Natural logarithms of Financial } \\
\text { openness index (plus }+1) \text {. }\end{array}$ & 350 & 0.3646 & 0.2443 & 0.000 & 0.6931 \\
\hline LnKPUBLIC & $\begin{array}{l}\text { Natural logarithms of per capita } \\
\text { General government capital stock } \\
\text { in billions of constant } 2011 \text { in } \\
\text { international dollars. }\end{array}$ & 350 & -12.1820 & 0.6760 & -13.2325 & -10.9931 \\
\hline
\end{tabular}

Notes: Obs. denotes the number of observations; Std. Dev. is the Standard Deviation; Min. and Max. are the minimum and maximum values, respectively; and ( $\mathrm{Ln})$ denotes variables in natural logarithms.

The variables IREC, GDP, and KPUBLIC are in per capita values. This allows controlling for disparities in population growth over time and within countries (e.g., Koengkan et al., [20]; Fuinhas et al., [11]). Furthermore, the use of constant GDP in LCU, rather than in constant US dollars, reduces the effects of inflation and foreign exchange variability [20]. 


\section{Empirical results}

This section presents the results of the preliminary and specification tests, and the estimated models. The first step was the computation of the VIF and CSD-tests. The VIF test informs on multicollinearity. The main objective of the CSD-test is the identification of variables' cross-section dependence (its null hypothesis is the presence of CSD). The results of both tests are displayed in Table 2.

Table 2. Variance Inflation Factor (VIF) and Cross-section Dependence (CSD) tests

\begin{tabular}{|c|c|c|c|c|c|c|c|}
\hline Variables & VIF & $1 / \mathrm{VIF}$ & CD-test & \multicolumn{2}{|c|}{$\mathrm{p}$-value } & Corr & Abs (corr) \\
\hline LnIREC & \multicolumn{2}{|c|}{ n.a. } & 29.17 & 0.000 & $* * *$ & 0.735 & 0.735 \\
\hline LnGDP & 1.04 & 0.9646 & 30.95 & 0.000 & $* * *$ & 0.780 & 0.780 \\
\hline LnFOPI & 1.08 & 0.9293 & 21.11 & 0.000 & $* * *$ & 0.532 & 0.570 \\
\hline LnKPUBLIC & 1.07 & 0.9379 & 4.24 & 0.000 & $* * *$ & 0.107 & 0.612 \\
\hline Mean VIF & \multicolumn{2}{|c|}{1.06} & & & & & \\
\hline DLnIREC & \multicolumn{2}{|c|}{ n.a. } & -0.280 & 0.780 & & -0.007 & 0.191 \\
\hline DLnGDP & 1.02 & 0.9759 & 13.39 & 0.000 & $* * *$ & 0.342 & 0.344 \\
\hline DLnFOPI & 1.07 & 0.9357 & 3.27 & 0.001 & $* * *$ & 0.084 & 0.168 \\
\hline DLnKPUBLIC & 1.04 & 0.9583 & 12.12 & 0.000 & $* * *$ & 0.310 & 0.392 \\
\hline Mean VIF & \multicolumn{2}{|c|}{1.05} & & & & & \\
\hline
\end{tabular}

Notes: *** denotes statistically significant at $1 \%$ level. The Stata command estat vif and $x t c d$ were used; ( $\mathrm{Ln}$ and DLn) denote variables in natural logarithms and first-differences of logarithms, respectively.

Results in Table 2 indicate that multicollinearity is not a concern. VIF and mean VIF values are lower than the usually accepted benchmark of 10 (in the case of the VIF, values are lower than 6). The null hypothesis for the CSD-test is not rejected in most cases (the exception being IREC in first differences).

When CSD is present, it is necessary to assess the order of integration of the variables. To this end, a second-generation unit root test, robust in the presence of CSD, is computed. We did not opt for a first-generation test because it is inefficient when CSD exists. The null hypothesis' rejection leads to concluding that the variable is I(1). The results of this test can be seen in Table 3.

Table 3. $2^{\text {nd }}$ generation unit root test (CIPS-test)

\begin{tabular}{|c|c|c|c|c|c|c|c|}
\hline \multirow{4}{*}{ Variables } & \multicolumn{7}{|c|}{$2^{\text {nd }}$ generation unit root test } \\
\hline & \multicolumn{7}{|c|}{ Pesaran (2007) Panel Unit Root test (CIPS) (Zt-bar) } \\
\hline & \multicolumn{4}{|c|}{ Without trend } & \multicolumn{3}{|c|}{ With trend } \\
\hline & Lags & Zt-bar & \multicolumn{2}{|c|}{ p-value } & Zt-bar & \multicolumn{2}{|c|}{ p-value } \\
\hline LnIREC & 1 & -2.725 & 0.003 & $* * *$ & -2.815 & 0.002 & $* * *$ \\
\hline LnGDP & 1 & -1.234 & 0.109 & & -1.224 & 0.111 & \\
\hline LnFOPI & 1 & -1.745 & 0.040 & $* *$ & 0.037 & 0.515 & \\
\hline LnKPUBLIC & 1 & 1.240 & 0.893 & & -0.983 & 0.163 & \\
\hline DLnIREC & 1 & -10.360 & 0.000 & $* * *$ & -9.084 & 0.000 & $* * *$ \\
\hline DLnGDP & 1 & -5.418 & 0.000 & $* * *$ & -4.887 & 0.000 & $* * *$ \\
\hline DLnFOPI & 1 & -7.815 & 0.000 & $* * *$ & -6.089 & 0.000 & $* * *$ \\
\hline DLnKPUBLIC & 1 & -5.853 & 0.000 & $* * *$ & -5.708 & 0.000 & $* * *$ \\
\hline
\end{tabular}

Notes: $* * *, * *$ denote statistically significant at $1 \%$, and $5 \%$ level, respectively;(Ln and DLn) denote variables in natural logarithms and first-differences of logarithms respectively The Stata command multipurt was used; The null for the CIPS test is: series are I(1); the lag length (1) and trend were used in this test. 
The CIPS test indicates that none of the variables seems to be I(2), although it shows that some are borderline between $\mathrm{I}(0)$ and $\mathrm{I}(1)$. Indeed, in first differences, all variables seem to be stationary. The same occurs for IREC and FOPI in natural logarithms. Furthermore, the nonstationarity of some variables, such as GDP and KPUBLIC in natural logarithms is an indication of potential "spurious correlation". Therefore, it is recommended to apply the second-generation cointegration test of Westerlund in order to check for cointegration between the variables which are not stationary. This test's null hypothesis is no-cointegration, and it requires that all variables are $\mathrm{I}(1)$. The results, displayed in Table 4, suggest that there is no cointegration between the assessed variables, as expected.

Table 4. Westerlund cointegration test between LnGDP and LnKPUBLIC

\begin{tabular}{ccc}
\hline \multicolumn{3}{c}{ Westerlund test (with constant ) } \\
\hline Statistics & Value & P-value robust \\
\hline $\mathrm{Gt}$ & -0.754 & 1.000 \\
$\mathrm{Ga}$ & -1.562 & 0.999 \\
$\mathrm{Pt}$ & -1.119 & 1.000 \\
$\mathrm{Pt}$ & -1.216 & 0.984 \\
\hline
\end{tabular}

Notes: $\mathrm{H}_{0}$ : No cointegration; $\mathrm{H}_{1} \mathrm{Gt}$ and $\mathrm{Ga}$ test the cointegration for each country individually and $\mathrm{Pt}$ and $\mathrm{Pa}$ test the cointegration of the panel as a whole; the Stata command xtwest was used.

Following the cointegration check, the next step is to assess the existence of individual effects. The Hausman test, confronting random (RE) and fixed effects (FE), is thus performed. The null hypothesis of this test is that the difference in coefficients is not systematic, i.e. random effects are the most suitable estimator. The results of the Hausman test indicate that the null hypothesis should be rejected (Chi2 (4) $=58.33$, statistically significant at $1 \%$ level), and that a fixed effects model is the most appropriate for this analysis.

Assessment of panel heterogeneity/homogeneity is performed with Mean Group (MG), Pooled Mean Group (PMG), and Fixed Effects (FE) techniques. Indeed, the MG estimator computes the average of coefficients of all individuals, with no restrictions regarding the homogeneity of the short-and long-run. This estimator was developed by Pesaran and Smith [39]. The PMG estimator, created by Pesaran et al., [40], allows for differences in error variances, short-run coefficients, speed of adjustment, and intercepts (i.e. these parameters may be country specific), but it imposes a homogeneity restriction on the long-run coefficients (i.e. they should be equal across countries). The PMG estimator combines the "pooling" from the FE estimator with the "averaging" from the MG estimator. In the case of panel homogeneity, this estimator is more efficient in the long-run, by comparison with MG. Table 5 shows the outcomes for the three specifications (MG, PMG, and FE).

Table 5. Heterogeneous estimators

\begin{tabular}{|c|c|c|c|c|c|c|}
\hline \multirow{2}{*}{$\begin{array}{l}\text { Independent } \\
\text { variables }\end{array}$} & \multicolumn{6}{|c|}{ Dependent variable (DLnIREC) } \\
\hline & \multicolumn{2}{|c|}{ MG } & \multicolumn{2}{|c|}{ PMG } & \multicolumn{2}{|c|}{$\mathrm{FE}$} \\
\hline Constant & 0.2003 & & 3.2983 & $* * *$ & 2.4368 & $* * *$ \\
\hline LnFOPI (-1) & 0.5284 & & 0.7099 & $* * *$ & 0.6284 & $* * *$ \\
\hline $\operatorname{LnKPUBLIC~(-1)~}$ & 0.0603 & & 0.7965 & $* * *$ & 0.7094 & $* * *$ \\
\hline ECM & -0.3370 & $* * *$ & -0.2796 & $* * *$ & -0.2209 & $* * *$ \\
\hline DLnGDP & 0.3317 & $*$ & 0.3472 & $* *$ & 0.2868 & \\
\hline
\end{tabular}

Notes: $* * *, * *, *$ denote statistically significant at 1\%, 5\%, and 10\% level, respectively; The ECM denotes the coefficient of the variable LnIREC, lagged once; the long-run parameters are computed elasticities. The Stata command xtpmg was used; (Ln and DLn) denote variables in natural logarithms and first-differences of logarithms respectively. 
Finally, the last of the preliminary tests consists of assessing panel heterogeneity/ homogeneity with the Hausman test. Results are displayed in Table 6 for the above-mentioned specifications (e.g., MG vs PMG; PMG vs FE; and MG vs FE) and suggest that the panel is homogeneous and that the FE is the most appropriate estimator.

Table 6. Hausman test

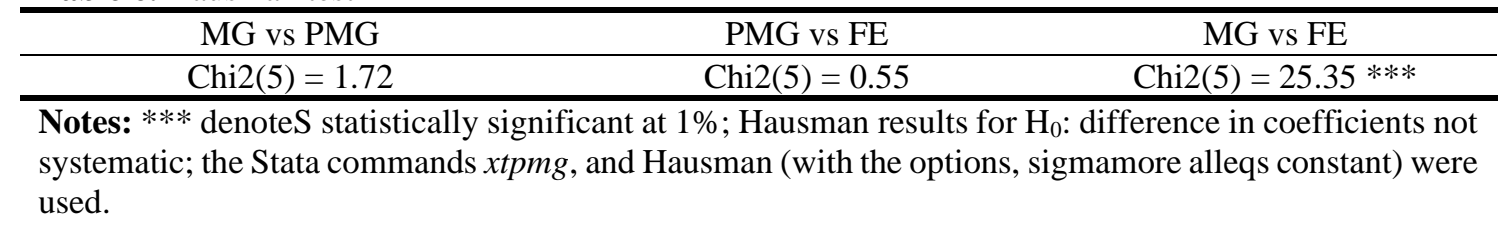

Before model estimation, the following specification tests are performed: (a) the Modified Wald test; (b) the Wooldridge test; and (c) the Breusch and Pagan Lagrangian Multiplier test. Results are presented in Table 7.

Table 7. Specification tests

\begin{tabular}{lccc}
\hline \multirow{2}{*}{ Statistics } & Modified Wald test & Wooldridge test & Breusch and Pagan LM test \\
\cline { 2 - 4 } & chi2 $(10)=3914.91 * * *$ & $\mathrm{~F}(1,9)=12.542 * * *$ & chi2(45)=79.734*** \\
\hline
\end{tabular}

Notes: $* * *$ denotes statistically significant at $1 \%$ level; $\mathrm{H}_{0}$ of Modified Wald test: $\operatorname{sigma}(\mathrm{i})^{\wedge} 2=\operatorname{sigma}^{\wedge} 2$ for all $\mathrm{i} ; \mathrm{H}_{0}$ of Wooldridge test: no first-order autocorrelation; $\mathrm{H}_{0}$ of Breusch and Pagan LM test' test: residuals are not correlated.

The null hypotheses of these tests are all rejected at the $1 \%$ level, indicating that heteroscedasticity, first-order autocorrelation, and cross-sectional correlation exist.

The FE-DK (Driscoll and Kraay) technique is thus adopted to estimate the model of interest in this empirical study. To obtain the long-run elasticities, each variable coefficient is divided by the LnIREC coefficient (in both cases lagged once). This ratio is then multiplied by (1). Table 8, displays the short-run impacts, the long-run elasticities, and the speed of adjustment.

Table 8. Model's estimation

\begin{tabular}{lc}
\hline \multirow{2}{*}{ Independent variables } & Dependent variable (DLnIREC) \\
\cline { 2 - 2 } Constant & FE D.-K. \\
\hline & $2.4368 * *$ \\
DLnGDP & Short-run (impacts) \\
& 0.2868 \\
LnFOPI (-1) & Long-run (elasticities) \\
LnKPUBLIC $(-1)$ & $0.6284 * * *$ \\
& $0.7094 * * *$ \\
ECM & Speed of adjustment \\
\hline
\end{tabular}

Notes: $* * *, * *$ denote statistically significant at $1 \%$ and $5 \%$ level, respectively; The ECM denotes the coefficient of the variable LnIREC lagged once; "Ln" and "DLn" denote variables in natural logarithms and first-differences of logarithms, respectively.

Results in Table 8 indicate that, in the short-run, the semi-elasticity of the per capita GDP does not contribute to increasing the installed capacity of renewable energy. In the long-run, the elasticities of financial openness (FOPI) and of per capita general government capital stock (KPUBLIC), are statistically significant at $1 \%$. In what concerns their long-run effects, both 
financial openness and general government capital stock contribute to increasing the installed capacity of renewable energy.

The ECM term is negative and statistically significant at the $1 \%$ level, indicating the presence of cointegration/long memory in the variables. This coefficient depicts the speed of the dependent variable's return to equilibrium which, in this case, is moderate.

During the period of analysis, Latin America experienced shocks that, if not taken into account, may produce inaccurate results. The following triple criterion was thus used to include dummies: (a) the occurrence of international events known to have disturbed the Latin America region; (b) the potential relevance of recorded economic, social, and political events at the country level; and (c) significant disturbances in the estimated residuals. The dummy variables added to the regression are the following: IDECUADOR1981 (Ecuador, year 1981); IDECUADOR1982 (Ecuador, year 1982); IDURUGUAY1983 (Uruguay, year 1983); IDURUGUAY2006 (Uruguay, year 2006); IDURUGUAY2007 (Uruguay, year 2007); IDURUGUAY2008 (Uruguay, year 2008); and IDURUGUAY2010 (Uruguay, year 2010). Table 9 shows the results of the corrected model, i.e. the short- and long-run elasticities, and the ECM for the FE D-K estimation after the inclusion of dummy variables.

Table 9. Model’s estimation corrected

\begin{tabular}{|c|c|c|}
\hline \multirow{2}{*}{ Independent variables } & \multicolumn{2}{|c|}{ Dependent variable (DLnIREC) } \\
\hline & \multicolumn{2}{|c|}{ FE D-K } \\
\hline Constant & 2.7653 & $* * *$ \\
\hline Shocks & \multicolumn{2}{|c|}{ Shocks } \\
\hline IDECUADOR1981 & -0.7003 & $* * *$ \\
\hline IDECUADOR1982 & -0.4698 & $* * *$ \\
\hline IDURUGUAY1983 & 0.8936 & $* * *$ \\
\hline IDURUGUAY2006 & -0.6055 & $* * *$ \\
\hline IDURUGUAY2007 & 0.6541 & $* * *$ \\
\hline IDURUGUAY2008 & -0.3808 & $* * *$ \\
\hline IDURUGUAY2010 & 0.4249 & $* * *$ \\
\hline \multicolumn{3}{|c|}{ Short-run (semi-elasticities) } \\
\hline \multicolumn{3}{|c|}{ Long-run (elasticities) } \\
\hline LnFOPI(-1) & 0.6371 & $* * *$ \\
\hline LnKPUBLIC (-1) & 0.7040 & $* * *$ \\
\hline \multicolumn{3}{|c|}{ Speed of adjustment } \\
\hline
\end{tabular}

Notes: $* * *, * *$ denote statistically significant at $1 \%$, and $5 \%$ level, respectively; The ECM denotes the coefficient of the variable LnIREC, lagged once; "Ln" and "DLn" denote variables in natural logarithms and first-differences of logarithms, respectively.

The results indicate that, in the short-run, the semi-elasticity of the per capita GDP is statistically significant at the $10 \%$ level, and thus that it contributes to increasing the installed capacity of renewable energy. In the long-run, the elasticities of FOPI and per capita KPUBLIC are statistically significant at $1 \%$ and thus both variables contribute to increasing the installed capacity of renewable energy in the Latin American countries. Regarding the ECM term, it continues to be negative and statistically significant at the $1 \%$ level.

\section{Robustness check}

In order to evaluate the robustness of the analysis developed so far, a PVAR model is estimated and Panel Granger causality Wald tests are computed. To this end, only variables in first-differences are used (LnIREC; DLnGDP; LnFOPI; and DLnKPUBLIC). Estimates for the PVAR model coefficients (lag length $=1$ ) are shown in Table 10. 
Table 10. Results of PVAR

\begin{tabular}{|c|c|c|c|c|c|c|c|c|}
\hline \multirow{3}{*}{$\begin{array}{l}\text { Response of } \\
\text { LnIREC (-1) }\end{array}$} & \multicolumn{8}{|c|}{ Response to } \\
\hline & \multicolumn{2}{|c|}{ LnIREC } & \multicolumn{2}{|c|}{ DLnGDP } & \multicolumn{2}{|c|}{ LnFOPI } & \multicolumn{2}{|c|}{ DLnKPUBLIC } \\
\hline & 0.8107 & $* * *$ & 0.0034 & $*$ & -0.0682 & $* * *$ & 0.0064 & $* * *$ \\
\hline $\operatorname{DLnGDP}(-1)$ & 0.5709 & $* * *$ & 0.7460 & $* * *$ & 0.2521 & $* * *$ & 0.1319 & $* * *$ \\
\hline LnFOPI (-1) & 0.1932 & $* * *$ & -0.0221 & $* * *$ & 0.9340 & $* * *$ & 0.0013 & \\
\hline DLnKPUBLIC(-1) & 1.3914 & $* * *$ & -0.2195 & $* * *$ & 0.0210 & & 0.9661 & $* * *$ \\
\hline$N$. obs & \multicolumn{8}{|c|}{210} \\
\hline$N$. panels & \multicolumn{8}{|c|}{10} \\
\hline
\end{tabular}

Notes: *** denotes statistical significance level of 1\%;(Ln and DLn) denote variables in natural logarithms and first-differences of logarithms respectively; the Stata command pvar with one lag was used. Instruments: $1(1 / 13)$

All variables in this model are I( 0$)$, and therefore, only short-run effects may be identified. The regression indicates that endogeneity exists. For DLnFOPI all estimates are statistically significant at $1 \%$ and $5 \%$.

Table 11 displays the results for the Panel Granger causality assessment performed with a Wald test.

Table 11. Panel Granger causality Wald test

\begin{tabular}{cc|ccc}
\hline \multicolumn{2}{c}{ Equation $\backslash$ Excluded } & chi2 & Df. & Prob > chi2 \\
\hline \multirow{3}{*}{ LnIREC } & DLnGDP & 129.278 & 1 & 0.000 \\
& LnFOPI & 72.985 & 1 & 0.000 \\
& DLnKPUBLIC & 86.582 & 1 & 0.000 \\
& All & 252.414 & 3 & 0.000 \\
\hline \multirow{2}{*}{ DLnGDP } & LnIREC & 2.748 & 1 & 0.097 \\
& LnFOPI & 19.995 & 1 & 0.000 \\
& DLnPUBLIC & 39.569 & 1 & 0.000 \\
& All & 50.843 & 3 & 0.000 \\
\hline & LnIREC & 664.102 & 1 & 0.000 \\
& DLnGDP & 165.402 & 1 & 0.000 \\
& DLnKPUBLIC & 0.220 & 1 & 0.639 \\
& All & 1289.596 & 3 & 0.000 \\
\hline & LnIREC & 143.158 & 1 & 0.000 \\
& DLnGDP & 2613.123 & 1 & 0.000 \\
DLnKPUBLIC & LnFOPI & 1.214 & 1 & 0.271 \\
& All & 2819.118 & 3 & 0.000 \\
\hline
\end{tabular}

Notes: (Ln and DLn) denote variables in natural logarithms and first-differences of logarithms respectively; the Stata command pvargranger was used.

These results indicate that bi-directional causality exists between: (i) the installed capacity of renewable energy and per capita economic growth; (ii) financial openness and the installed capacity; (iii) financial openness and per capita economic growth; (iv) the installed capacity of renewable energy and per capita general government capital stock; and (v) per capita general government capital stock and per capita economic growth. Fig. 1 summarises the statistically significant Panel Granger causality links. 


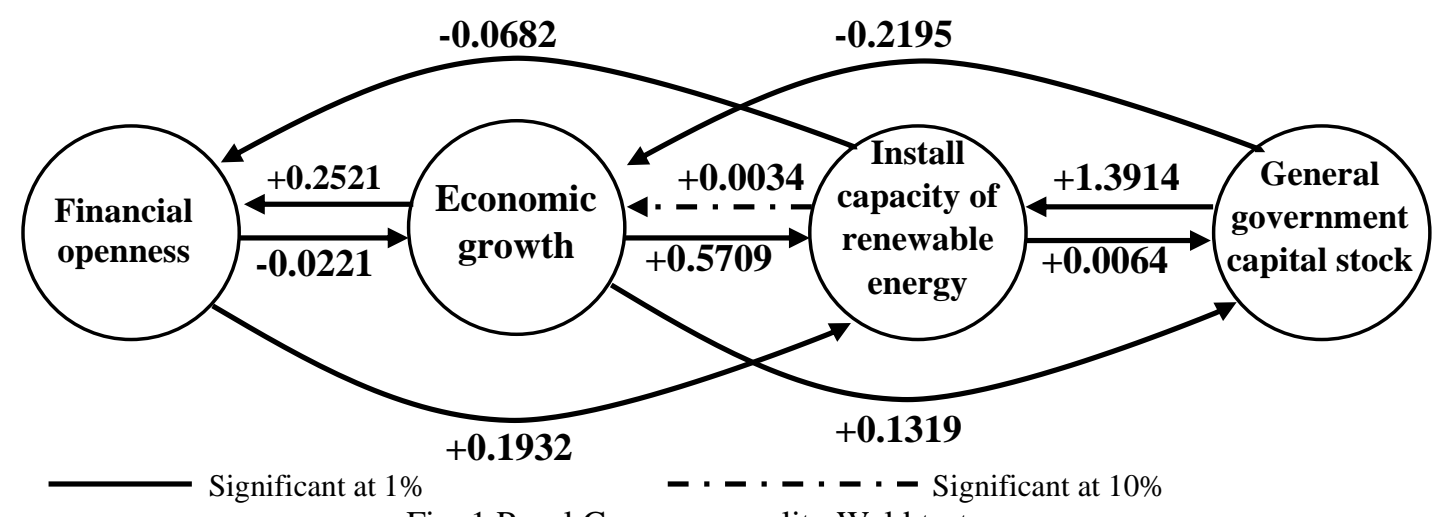

Fig. 1 Panel Granger causality Wald test.

Results of the empirical analysis are discussed in the following section.

\section{Discussions}

The effect of financial openness on renewable energy investments diffusion in ten Latin American countries was investigated. The results of the developed preliminary tests suggest that low multicollinearity and CSD are present in the data, in the latter case with the exception of the variable IREC in first-differences (see Table 2). Despite the absence of CSD in the last case, we conclude that there is a correlation amongst series, across the countries comprised in the panel of data. This runs mainly from the interdependence of the examined countries' economies. All variables in first-differences, and also the levels of IREC and FOPI in natural logarithms, are stationary (see Table 3), indicating that the ARDL is the best regression methodology as it allows working with series displaying distinct orders of integration. The variables GDP and KPUBLIC in natural logarithms are not cointegrated (see Table 4). This was assessed to prevent a "spurious correlation" problem in the estimated model. The results of this test supported the use of an econometric technique less stringent concerning the order of integration of the series, i.e. the PARDL methodology. The FE technique was selected as the most appropriate for the fixed effects homogeneous model (see Tables 5 and 6).

The specification tests indicated that heteroscedasticity, first-order autocorrelation, and cross-sectional correlation exist (Table 7). Therefore, the FE-Driscoll and Kraay [9] estimator was used as it produces standard errors robust to the identified problems (and is superior to both $\mathrm{FE}$ and $\mathrm{FE}$ robust estimators).

Dummy variables were introduced to account for shocks (peaks and breaks of significant magnitude) occurred in some Latin American countries, identified in the analysis of the residuals. The Latin American region experienced social and economic crises during the 1980s, 1990s, 2000s. For instance, in 1981, Ecuador entered a brief territorial dispute with Peru [43]. This coincided, with problems in the Ecuadorian economy, following from a decline in international oil prices [15]. In 1982, the economy of Ecuador was hit by dramatic climate events triggered by El Niño which produced torrential rains, coastal floods, and a severe drought, with highly negative consequences for crops, infrastructures and transportation. The country's external debt grew (reaching US\$8.4 billion in 1984), and the foreign sources of credit dried up in 1982, leaving the national government and hundreds of state-owned companies without capital [15].

The Latin American debt crisis, which began in 1982 with Mexico's announcement of incapacity to service its debt, reached Uruguay in 1983. External suppliers of capital became increasingly difficult to find and, in November of that year, a stabilisation plan was abandoned. 
The peso was devalued by $149 \%$ against the US dollar and the annual inflation climbed from $20.5 \%$ in 1982 to $51.5 \%$ in 1983 . The large stock of dollar-denominated debt of the private sector quickly caused solvency problems, triggering a banking crisis [38]. The country eventually recovered and the span from 2004 to 2014 is considered as a golden period for the Uruguayan economy. During this period, the GDP annual growth rate reached 5.4\%, three times the growth registered in the second half of the twentieth century, fuelled by a super cycle of commodity prices, good financial conditions in emerging markets, and strong external demand, especially after the 2008 international financial crisis [38]. In 2006, the GDP annual growth rate was $4.09 \%$, escalating to $6.54 \%$ in $2007,7.17 \%$ in 2008 , and $7.80 \%$ in 2010 [46]. All these events were represented by the following dummy variables: IDECUADOR1981; IDECUADOR1982; IDURUGUAY1983; IDURUGUAY2006; IDURUGUAY2007; IDURUGUAY2008; and IDURUGUAY2010.

The estimated general model (including the dummies) suggests that the semi-elasticity of the variable per capita GDP has a positive impact of 0.2318 on the installed capacity of renewable energy, while the elasticities of the variables FOPI and per capita KPUBLIC have positive impacts of 0.6371 and 0.7040 , respectively (see Table 9). According to Koengkan [24], the possible explanation for the positive effect of economic growth on the installed capacity of renewable energy is the latter's sensitivity to changes in the economic dynamics of Latin American countries. Higher economic growth in these countries has a positive impact on the consumption of energy. In order to meet such increased energy demand, promoted by the enhanced economic activity, more investments in renewable energy sources are required. Another possible justification is that the abundance of renewable energy resources in the region stimulates investments in this kind of technology and, consequently, positively impacts economic activity and the consumption of energy [24].

The robustness analysis, with the estimation of a PVAR model and Panel Granger causality testing, are in line with these justifications. The estimated PVAR model indicates that per capita economic growth has a positive impact of 0.5709 , while the installed capacity of renewable energy has a positive impact of 0.0034 (short-run impacts in both cases) (see Table 11). The causality assessment points to positive bi-directional links between the variables (see Table 11, and Figure 1).

Some explanations that have been put forward to justify the positive effect of the capital stock on the installed capacity of renewable energy may also be of use when considering, as we do here, the public stock of capital. Thus, a possible reason for its positive impact on the installed capacity of renewable energy follows from the fact that increased capital supply reduces financing costs, promoting economic activity and energy consumption. In order to meet the increase in energy demand, investments in installed capacity of energy also grow (e.g., Lee and Chien [29]; Lee et al. [28]). In this line of reasoning, economic dynamics channels the impact of the capital stock to the installed capacity of renewable energy. We tried to corroborate this with a PVAR model and with the Panel Granger causality testing, but the results indicate that economic growth has a positive impact of 0.2521 on financial openness, while financial openness has a negative impact of -0.0221 on economic activity (both are short-run impacts). Granger causality analysis indicates that there is a bi-directional relationship (see Tables 10, 11, and Figure 1). A positive impact from financial openness on economic activity was anticipated for the Latin America region, given that in this area public capital drives economic growth.

Other possible explanations for the context of the Latin America region have been pointed out. According to Lee [27], the capital stock has an indirect effect on consumption and investments in energy. This is also defended by Lee and Chien [29] and Lee et al., [28]. The stock of capital positively impacts investment and industrial production which, in turn, increase the 
demand for energy and investments in installed capacity. Narayan and Smyth [32] and Apergis and Payne [4] have a different vision about this positive impact. According to them, the capital stock encourages investments in renewable energy because the supply of cheaper credit makes alternative energy sources more feasible. This can lead to an acceleration of economic growth and of energy consumption, and consequently to more investment in installed capacity.

Finally, although no studies have previously assessed the link between financial openness and the installed capacity of renewable energy, some justifications have also been put forward concerning the positive effect exerted by financial development and its proxies. Kim and Park, [25] and Sbia et al., [36] defended that financial development increases the capital stock and consequently reduces the cost of external financing, encouraging investments in renewable energy technologies. Mazzucato and Semieniuk [30] concur and state that financial development increases public and private capital stocks. However, they conclude that only the public capital is capable of promoting renewable energy investments, as the private sector is more risk-averse in this context, and that public policies have not been capable of mobilising the private sector (Mazzucato and Semieniuk [30]; Rodríguez et al., [35]). The positive effect of public capital on the installed capacity of renewable energy is also a result of our empirical analysis.

Koengkan et al., [21], Shahbaz et al., [37], and Islam et al., [17] defended a slightly different point of view, stating that the impact of financial openness on the installed capacity of renewable energy is indirect. In fact, the reduced cost of credit resulting from more financial integration boosts the consumption of goods and services and, consequently, the dynamics of economic activity and the consumption of energy. In order to meet this increased energy demand, more investments in installed capacity of renewable energy are made. We used our robustness check and causality analysis to examine this line of reasoning but, as mentioned above, our results indicate that there is a negative impact (of -0.0221) from financial openness on economic growth and a positive effect of 0.1932 on installed capacity of renewable energy (both are short-run effects - see Table 10). Granger causality points to the existence of bi-directional relationships between the variables (see Table 11, and Figure 1).

Regarding the ECM, it is negative and statistically significant at the $1 \%$ level, which indicates that the model is robust (See Table 09). Moreover, the statistical significance of the dummy variables supports the decision to include them. In fact, they improved the quality of the estimated model and showed the real effects of the independent variables.

\section{Conclusions and policy implications}

The aim of this empirical analysis was to assess the impact of financial openness on renewable energy investments diffusion. Ten Latin American countries were considered, and data was collected for the period 1980 to 2014. Results of a PARDL model's estimation suggest that, in the short-run, per capita economic growth has a positive impact on the installed capacity of renewable energy. In the long-run, both financial openness and the per capita general government capital stock exert positive effects. A possible explanation for the positive effect of financial openness is the decrease in financing costs it promotes. Less expensive credit increases consumption of goods and services, thus enhancing economic activity and energy consumption, which on its turn boosts investments in the installed capacity of renewable energy.

The estimated PVAR model and Panel Granger causality assessment were performed as robustness checks and pointed to the same results (although solely in the short-run). Bi-directional causality was identified between the following variables: installed capacity of renewable energy and per capita economic growth; financial openness and installed capacity; general government capital stock per capita and installed capacity of renewable energy; per capita economic growth 
and financial openness; and finally per capita general government capital stock and per capita economic growth.

This study suggests that financial institutions in the Latin America region should take advantage of the increase in the stock of public/private capital promoted by financial openness and promote investment in research and development activities related to renewable energy sources. This could lead to increase in the involvement of domestic financial institutions in environmentally relevant activities. Additionally, policymakers in Latin American countries should implement policies aimed at not only encouraging the participation of financial institutions in the funding of small and micro firms dedicated to low environmental impact projects but also at increasing households' preferences towards greener.

\section{References}

[1] Abrigo M.R.M.; Love I., (2015). Estimation of Panel Vector Autoregression in Stata: A Package of Programs. The University of Hawai'i at Mānoa Department of Economics, Working Paper Series, URL: http://www.economics.hawaii.edu/research/working.papers/WP 16-02.pdf. [2] Antonakakis N.; Chatziantoniou L.; Filis G., (2017). Energy consumption, CO2 emissions, and economic growth: An ethical dilemma. Renewable and Sustainable Energy Reviews, 68(1): 808-824. https://doi.org/10.1016/j.rser.2016.09.105.

[3] Aydin M., (2019). The effect of biomass energy consumption on economic growth in BRICS countries: A country-specific panel data analysis. Renewable Energy, 138: 620-627. doi: https://doi.org/10.1016/j.renene.2019.02.001.

[4] Apergis N., Payne J.E., (2010). Renewable energy consumption and economic growth: Evidence from a panel of OECD countries. Energy Policy, 38(1): 656-660. doi: https://doi.org/10.1016/j.enpol.2009.09.002.

[5] Aizenman J., (2005). Financial Liberalizations in Latin America in the 1990s: A reassessment. NBER working paper series, $\mathrm{n}^{\circ} 11145$, pp: 1-30.

[6] Balza L.H., Espinasa R., Serebrisky T., (2016). Lights on? Energy Needs in Latin America and the Caribbean to 2040. Inter-American Development Bank, pp. 1-39.

[7] Breusch T.S, Pagan A.R., (1980). The Lagrange multiplier test and its applications to model specification in econometrics. The Review of Economic Studies, 47(1): 239-253.

[8] Chinn M.D., Ito H., (2008). A New Measure of Financial Openness. Journal of Comparative Policy Analysis, 10(3): 309-322. doi: 10.1080/13876980802231123.

[9] Driscoll J.C., Kraay A.C., (1998). Consistent Covariance Matrix Estimation with Spatially Dependent Panel Data. Review of Economics and Statistics, 80(4), 549-560. https://doi.org/10.1162/003465398557825.

[10]Engle R., Granger G., (1987). Cointegration and Error Correction: Representation, Estimation and Testing, Econometrica, 55: 251-276.

[11] Fuinhas J.A., Marques A.C., Koengkan M., (2017). Are renewable energy policies upsetting carbon dioxide emissions? The case of Latin America countries. Environmental Science and Pollution Research, 24(17): 15044-15054. doi: https://link.springer.com/article/10.1007/s11356017-9109-z.

[12] Granger C.W.J., (1981). Some Properties of Time Series Data and Their Use in Econometric Model Specification, Journal of Econometrics, 28: 121-130.

[13] Greene W., (2002). Econometric Analysis. Upper Saddle River, New Jersey: Prentice-Hall. [14] Holtz-Eakin D.; Newey W.; Rosen H.S., (1988). Estimating vector autoregressions with panel data. Econometrica, 56(6): 1371-1395. http://www.jstor.org/stable/1913103.

[15] Hanratty D.M., (1989). Ecuador: a country study. Washington, D.C. : Federal Research Division, Library of Congress, pp. 1-341. https://lccn.loc.gov/91009494.

[16] IMF, Investiments and Capital Stock, (2017). https://www.imf.org/external/np/fad/publicinvestment/data/data122216.xlsx. 
[17] Islam F., Shahbaz M., Ahmed A.U., Alam M., (2013). Financial development and energy consumption nexus in Malaysia: a multivariate time series analysis. Econ Model 30: 435-441. https://doi.org/10.1016/j.econmod.2012.09.033

[18] IRENA (International Renewable Energy Agency), (2016). Renewable Energy Market Analysis: Latin America, pp.1-160. ISBN 978-92-95111-49-3.

[19] Johansen J., Juselius K., (1990). Maximum Likelihood Estimation and Inference on Cointegration-with Applications to the Demand for Money. Oxford Bulletin of Economics and Statistics, 52(2): 169-210.

[20] Koengkan M., Fuinhas J.A., Marques A.C., (2019). The role of financial openness and China's income on fossil fuels consumption: fresh evidence from Latin American countries. GeoJournal, pp.1-15. doi: https://doi.org/10.1007/s10708-019-09969-1.

[21] Koengkan M., Fuinhas J.A., Marques A.C., (2018). Does financial openness increase environmental degradation? Fresh evidence from MERCOSUR countries. Environmental Science and Pollution Research 25(30): 30508-30516. doi: https://doi.org/10.1007/s11356-018-3057-0.

[22] Koengkan M., (2018). The decline of environmental degradation by renewable energy consumption in the MERCOSUR countries: an approach with ARDL modeling. Environment Systems and Decisions, 38(3): 415-425. doi: https://doi.org/10.1007/s10669-018-9671-z.

[23] Koengkan M., (2017a).The nexus between energy consumption, economic growth, and urbanization in Latin American and Caribbean countries: An approach with the PVAR model. Revista Valore, 6(2):202-218. doi: 10.22408/reva22201761\%25p.

[24] Koengkan M., (2017b).The nexus between consumption of biofuels and economic growth: An empirical evidence from Brazil. Cadernos UniFOA, Volta Redonda, 12(35):87-98. ISSN: 1809-9475.

[25] Kim J., Park K., (2016). Financial Development and Renewable Energy Diffusion. Energy Economics, 59:238-250. doi: https://doi.org/10.1016/j.eneco.2016.08.012.

[26] La Torre, A., Ize A., Schmukler S.L., (2012). Financial Development in Latin America and the Caribbean: The road ahead. World bank latin american and caribbean studies, $\mathrm{n}^{\circ} 65744, \mathrm{pp}$. $1-278$.

[27] Lee C.-C., (2005). Energy consumption and GDP in developing countries: A cointegrated panel analysis. Energy Economics, 27(3): 415-427. doi: https://doi.org/10.1016/j.eneco.2005.03.003.

[28] Lee C.-C., Chang C-P., Chen P-F., (2008). Energy-income causality in OECD countries revisited: The key role of capital stock. Energy Economics, 30(5): 2359-2373. doi: https://doi.org/10.1016/j.eneco.2008.01.005.

[29] Lee C.-C., Chen P-F., (2010). Dynamic modelling of energy consumption, capital stock, and real income in G-7 countries. Energy Economics, 32(3): 564-581. doi: https://doi.org/10.1016/j.eneco.2009.08.022.

[30] Mazzucato M., Semieniuk G., (2018). Financing renewable energy: Who is financing what and why it matters. Technological Forecasting and Social Change, 127: 8-22. doi: https://doi.org/10.1016/j.techfore.2017.05.021.

[31] Nkoro E., Uko A.K., (2016).Autoregressive Distributed Lag (ARDL) cointegration technique: application and interpretation. Journal of Statistical and Econometric Methods, 5(4): 63-91. ISSN: 1792-6602.

[32] Narayan P.K., Smyth R., (2008). Energy consumption and real GDP in G7 countries: New evidence from panel cointegration with structural breaks. Energy Economics, 30(5): 2331-2341. doi: https://doi.org/10.1016/j.eneco.2007.10.006.

[33] Rifkin J., (2011). The third industrial revolution. New York: Palgrave Macmillan.

[34] Roubaud D., Shahbaz M., (2018). Financial Development, Economic Growth, and Electricity Demand: A Sector Analysis of an Emerging Economy. Munich Personal RePEc Archive, Paper No. 87212, pp. 1-56. https://mpra.ub.uni-muenchen.de/87212/1/MPRA_paper_87212.pdf.

[35] Rodríguez M. C., Haščič I., Johnstone N., Silva J., Ferey A., (2014). Inducing Private Finance for Renewable Energy Projects. OECD Environment Working Papers, $n^{\circ}$ 46, 1-42. doi: https://doi.org/10.1787/5jxvg0k6thr1-en. 
[36] Sbia R., Shahbaz M., Hamdi H., (2014). A contribution of foreign direct investment, clean energy, trade openness, carbon emissions and economic growth to energy demand in UAE. Economic Modelling, 36:191-197. doi: https://doi.org/10.1016/j.econmod.2013.09.047.

[37] Shahbaz M., Hye Q.M.A., Tiwari A.K., Leitão N.C., (2013).Economic growth, energy consumption, financial development, international trade and $\mathrm{CO} 2$ emissions in Indonesia. Renewable \& Sustainable Energy Reviews 25: 109-121. https://doi.org/10.1016/j.rser.2013.04.009.

[38] Oddone G., Marandino J., (2018). The Monetary and Fiscal History of Uruguay 1960-2017. Becker Friedman Institute: For economics at the University of Chicago, working paper $n^{\circ} 60$, pp.1-34. https://bfi.uchicago.edu/sites/default/files/file_uploads/WP_2018-60.pdf.

[39] Pesaran M.H., Smith R., (1995). Estimating long-run relationships from dynamic heterogeneous panels. Journal of Econometrics, 68(1): 79-113. https://doi.org/10.1016/03044076(94)01644-F.

[40] Pesaran M.H., Shin Y., Smith R.P., (1999). Pooled mean group estimation of dynamic heterogeneous panels. Journal of American Statistical Association, 94(446): 621-634. URL: http://www.jstor.org/stable/2670182.

[41] Pesaran M.H., (2004). General diagnostic tests for cross section dependence in panels. The University of Cambridge, Faculty of Economics. Cambridge Working Papers in Economics, n. 0435 .

[42] Pesaran M.H., (2007). A simple panel unit root test in the presence of cross-section dependence. Journal of Applied Econometrics, 22(2): 256-312. doi: 10.1002/jae.951.

[43] Villamar C.M., (1981). Paquisha: toda la verdade. Letra Nueva, Quito.

[44] Westerlund J., (2007). Testing for error correction in panel data. Oxford Bulletin of Economics and Statistics 69: 709-748.

[45] Wooldridge J.M., (2002). Econometric analysis of cross section and panel data. The MIT Press Cambridge, Massachusetts London, England.

[46] World Bank Data., (2019). Available in http://www.worldbank.org/.

[47] UN Commission on Sustainable Development, (2007). Report on the fifteenth session. Economic and Social Council Official Records, Supplement No. 9.

[48] International Energy Agency (IEA). (2018). Available in: https://www.iea.org/energyaccess/database/. 